\title{
Determination of the Effects of Alucra Forest Planning Unit's Population Dynamics on Land Use Changes
}

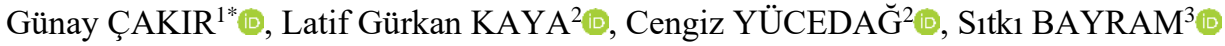 \\ ${ }^{1}$ Gümüşhane University, Gumushane Vocational School, Department of Forestry, 29100, Gümüşhane, \\ Turkey \\ ${ }^{2}$ Mehmet Akif Ersoy University, Department of Landscape Architecture, 15030, Burdur, Turkey \\ ${ }^{3}$ Gümüşhane University, Department of Forestry and Environmental Science, 29100, Gümüşhane, Turkey \\ "Corresponding author: cakirgunay@gmail.com
}

Received Date: 10.06 .2018

Accepted Date: 31.12 .2018

\section{Abstract}

Aim of study: This study is done to monitor temporal land use/land cover changes in a typical mountain watershed covering an area of 135441.0 ha in North Eastern of Turkey based on rural demographic dynamics and forest management plans belonging to the years 1987 and 2013 coupled by GIS analyses. It also investigates changes in the shape of land use class (LUC) over the period.

Material and Methods: The changes occurring time wise and positional on the base of the local LUC was examined by benefiting from the forest management plans from 1987 to 2013. Moreover, the change of LUC around these areas has been examined with the $1000 \mathrm{~m}$ zones thrown around the settlement areas and correlated with the fast decrease of the population recent years. Demographic dynamics (increase or decrease) affect the usage of forest lands, as well.

Main results: While there was an increase in the productive forest lands (pure coniferous and deciduous, and mixed forest) between 1987 and 2013. In the same periods there was a decrease in agricultural and sandy areas. The increase of patches in the productive forest lands mostly resulted from afforestation works conducted in the unproductive forest lands, and forestry maintenance activities. Another reason for this increase of forest patches is why people have immigrated to urban areas in the last years.

Research Highlights: It can be said that one of the most important causes in the rise of the forest resources in the Alucra Forest Planning Units (FPU) is the time wise changes of social structure. Furthermore, the forestry activities in the study between 1987 and 2013 are also the other significant factor in this increase of forest resources.

Keywords: Alucra, forest management plan, immigration, land use change

\section{Alucra Orman İșletme Şefliği Içindeki Nüfus Dinamiğinin Arazi}

\section{Kullanım Değişimlerine Olan Etkisinin Belirlenmesi}

$\ddot{\mathbf{O} z}$

Çalışmanın Amact: Bu çalışma, tipik dağlık bir havza içeresinde 135441.0 ha alanda 1987 ve 2013 yllı orman amenajman planı verilerine ve nüfus dinamiğine bağlı olarak arazi kullanımında oluşan değişimlerin izlenmesi için yapılmıştır. Aynı zamanda bu çalışma arazi kullanım sınıfının (LUC) şeklindeki zamanla oluşan değişimleri incelemektedir.

Materyal ve Yöntem: Arazi kullanım değişikliklerin zaman ve mekan boyutunda izlenmesi için, 1987 ve 2013 yılı orman amenajman planlarından yararlanılmıştır. Ayrıca, çalışma alanındaki arazi kullanım değişimi için yerleşim alanları etrafında $1000 \mathrm{~m}$ zonlama içerisinde incelenmiş ve aynı alanlardaki nüfusun azalması ile ilişkilendirilmiştir. Nüfus dinamikleri (artış veya azalma) orman arazileri üzerindeki kullanım şekillerini de etkilemiştir.

Sonuçlar: 1987 ile 2013 yılları arasında; verimli orman arazileri (saf iğne yapraklı, saf geniş yapraklı ve karışık orman) alanlarında artış olurken, tarım ile kumlu arazilerde azalma meydana gelmiştir. Verimli orman alanlarındaki parça sayılarının artması çoğunlukla bozuk veya verimsiz orman alanlarının ağaçlandırılma çalışmalarından gerçekleşmiş̧tir. Bu artışın nedenleri insanların kentlere göç etmesi ve bakım faaliyetleridir.

Araştırma vurguları: Alucra Orman Planlama Biriminde orman kaynaklarının artmasının en önemli nedenlerinden birinin sosyal yapının zaman içinde önemli ölçüde değişimi olduğu söylenebilir. Ayrıca çalışma alanındaki 1987 ve 2013 yılları arasında ormancılık faaliyetleri de bu artışta önemli bir faktör olmuştur.

Anahtar Kelimeler: Alucra, orman amenajman planı, göç, arazi kullanım değişimi 


\section{Introduction}

Natural events or unplanned interventions of people have influenced the changes in the dynamics of the forest ecosystem over the last 50 years. Comprehensive utilization activities have stressed the increasing exigency for improve land cover information in the natural planning (Bayram, 2014). The rating of the change in the forest ecosystems varies depending on the way of the human's benefiting degree and type, intensity and efficiency of the natural events. It is necessary to determine in the land use covers in order to past, present or future the land facilities into the society's service rationally on the sustainability base. Identifying the impacts of changes in land use types in Turkey's forests are being created to help assess both the impact of socio-economic structure of the planning of the forest (Vitousek et al., 1997; Çakır, 2006).

Landscape management has become an important issue in many countries. Key concepts in connection with landscape management have resulted in a vast change last 30 years (Naiman, Bisson \& Turner, 1997; Bhatta, Chalise, Myint \& Sharma, 1999). It should become together component of the sustainable development of forest resources with the local population (Sharma and Krosschell, 1996). Management of natural resources requires of understanding the relationship between forests and human activities (Naiman et al., 1997). The land use patches are important characteristics for detecting the processes and effects of land use change at the landscape level.

One of the concept is related to decrease of forest ecosystems fragmentation and preservation of fragmented ecosystems at the local as well as regional level (Laurance and Bierregaard, 1997). Partition of the woody land plays an important indicator role within variation of species in natural habitat fragmentation. (Kammerbauer and Ardon, 1999). Analysis and presentation of such data, on the other hand, can be significantly facilitated through the use of GIS technology. Therefore, the determined landscape changes can be invaluable to address a wide variety of resource management problems.

Karanth, Curran \& Reuning-Scherer (2006) studied the associations of cover change and biodiversity loss with specific ecological community's thirteen villages in Bhadra Reserve in India. The results of the spatial analysis showed that the size of the case villages, away from the village, and the proximity to other villages were the main reasons of land use changes in the structure and forest disturbance around them. They also found that forest disturbance increases relying on the distance from the village center. In some previous studies (Karanth et al., 2006; Triantakonstantis, Kollias, \& Kalivas, 2006; Kelarestaghi and Jeloudar 2011; Şen, Güngör \& Şevik, 2018), spatial analysis was used to evaluate the factors influencing land cover, while similar studies have also been used in other studies conducted on a national scale. (Jin-feng, Guo-jie \& Zhong, 2005; Huang, Cai $\&$ Peng, 2007). The changing from forest to agriculture land and urbanization have unconformable changed forest dynamics in land cover surface everywhere (Giri, 2012). It may have good or bad effects on human wellbeing and also have intended or unintended consequences (De Fries and Belward, 2000; Hensen and De Fries, 2004).

On the other hand, the forest management plans has been served information regarding the forest's structure, while it can submitting the comprehensive oldest data related to the positional structure of the forest's ecosystem.

Today, rapid land cover changes in Turkey are considered as one of the most important causes of environmental change. Particularly damaging of forests and improper use of forestry area, convert from the forest to the agricultural land, pasture or different land covers are the clearest samples of those changes. In the opinion of Food and Agriculture Organization of the United Nations (FAO), it is recorded that there was not any increase in the forestlands in Turkey through the years 1983-1993 but there was an increase at rate of $3.44 \%$ in the agricultural fields at that time (FAO, 1994; Tunay and Ateşoğlu 2004). Turkish National Forestry Strategy is reforestation of degraded forest, forest openings and non-forest lands. The Turkish General Directorate of Forestry (GDF) performed reforestation and plantation activities in approximately two million hectare forest lands from 1946 to 2013 (GDF, 2013). 
These applications in the forests by the GDF showed that the forests have dynamic structure. It is necessary to follow the features of the forests having this dynamic structure in the specific intervals. The computer based innovative technology is used for following these features. Information about forests and surrounding environment; the recording of the data obtained or analysed by remote sensing can be achieved by combining ground interpretation and measurement data. The remote sensing information is regarding observation and measurement of the objects without any physical contact with the ground.

The aim of the study is to determine and evaluate to change in the LUC structure between 1987 and 2013 when is particularly by benefiting from forest management plans by ensure data related to the resources of forest dynamics. In this scope, the forest management plan database has been prepared by using the remote sensing data 1987- 2013 with be interested in to the study area and these data can be form an area inventory base to the next plan (Anonymous, 1987; Anonymous, 2013).

Remote sensing and GIS activities in the forestry sector in Turkey, has recently been used in many fields of science. These studies are areas such as modeling of fire behavior (Yavuz, Sağlam, Küçük \& Tüfekçioğlu, 2018), ecosystem based forest planning, conservation of biological diversity, forest management approaches (Çakır, 2012; Günlü \& Başkent, 2017; Zaimes, Kayıoglu \& Kozanidis, 2017) operational planning and management of protected areas (Çakır, Köse \& Başkent, 2010).

In the study, it is aimed at (i) detecting and documenting changes in land use in forests and other area in particular in a representative mountain watershed in Alucra Planning Units in between 1987 and 2013, and (ii) analyzing patterns of changes in the landscape of the case area during the 26-year period, with special focus on forest fragmentation.

Similarly, the time wise occurred change shall be analyzed as a position rather than explaining as a quantity. Both the forest structure of the area to be worked and the population change according to the years were determined by The Digitized Maps of the Forest Management Plans in the years 1987 and 2013 of the Alucra FPU of the Forest Region Directorate of Giresun in Turkey. The projection system was The Universal Transversal Mercator (UTM) coordinate system WGS84 Zone 37.

The positional database was obtained by the forest management plans made in GDF. The change in the forestlands examined and interpreted on the base of the stand type by the help of all data in forest management plans.

\section{Experimental Section Case Area}

The case area is Alucra Forest Planning Units (460000-507000 E, 4432000-4484000 $\mathrm{N})$ covering an area of 135441.0 hectare in the Northeastern part of Turkey (Figure 1). The altitude varies between 1100 and $2900 \mathrm{~m}$ above sea level. Its climate is Black sea climate zones.

The higher elevation (above 2000 meters asl) is cool-temperate type. The climate is warm-temperate and humid temperate from 0 m to 2000 meters about sea level. Agricultural lands are major crops in paddy, potato, wheat and vegetables the in valleys where are under intensive management with multiple cropping systems and are mostly irrigated.

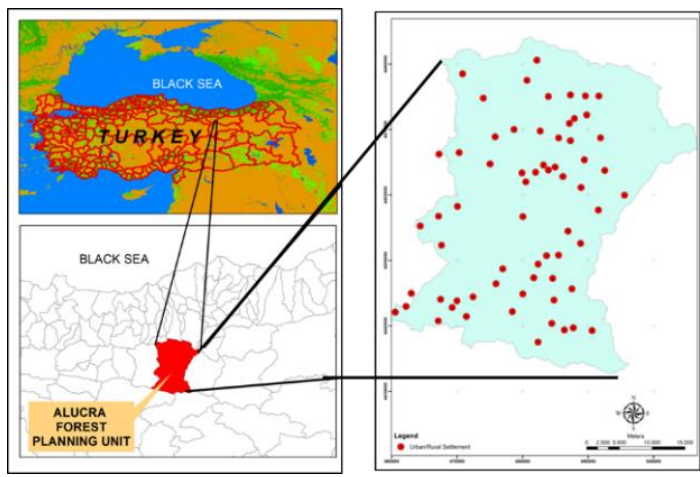

Figure 1. Location of Alucra Forest Planning Unit and settlement areas

Forests are mostly limited to upwards slopes and consist of both natural mixed hardwood and pine plantations. A single large block natural forest in the Black Sea Mountain Region represents about $70-80 \%$ of the total forest area of the watershed. Alucra Forest Planning Unit's location also determines its climatic characteristics. This feature is the transition between the Black Sea region of Turkey's and Central Anatolian climate with 
humid climate causes it to the structure. While the annual precipitation is $572.2 \mathrm{~mm}$ and the temperature average is $9^{\circ} \mathrm{C}$. The prevailing wind direction is the northeast (Bayram, 2014). Alucra FPU is within the administrative borders of Giresun Province in the North Eastern Black Sea. It is far from 108 $\mathrm{km}$ to Giresun and its mean elevation is 1405 m. It is closed by the Kiliçkaya Dam Lake (URL-1, 2015). Most of the people around of the Alucra FPU have been breeding the sheep, goats and herds.

\section{Methods}

The materials was a forest management plans formed by the result of the ground surveying measurements 1987-2013 of the Alucra FPU, the Forest Administration Regional Directorate of Giresun (Bayram, 2014). In addition, the centers of the village areas and population information were also used.

The spatial database, developed as part of this study, consisted of forest stand type maps derived from remote sensing data (aerial photographs that is $1 / 22000$ panchromatic and $1 / 15000$ color infrared, and satellite images that is a meter resolution IKONOS) and field survey. Data on remote sensing of the study area was obtained from General Directorate of Forestry (GDF). Forest management plan had been jointly both remote sensing techniques and field survey data in 1987 and 2013. The maps errors were using a maximum root mean square (RMS) error under 1 meters in GIS. The derived attribute data was entered in the
GIS to consist of spatial database of the area (Çakır, 2006).

The change of forests was put along by benefiting from the development ages, the land cover types, closeness of settlement area in the types of stand layer. On the other hand, the maps of the buffer zones in settlement areas where also put forth the impact of population formed was detect in land cover types (Table 1). The land cover layer in the digitized map by the help of the ArcInfo 9.3 in the database was used in these plans.

Geographical projection system was the UTM WGS84 Zone 37 in the study. Then, forest management plan databases in 1987 and 2013 were overlapped with the land usage and buffer zone settlement area database. In addition, a 1000-meter radius (protection zone) zone was placed around settlements to determine the effect of population change on forest ecosystem. On the other hand, the buffer with the radiuses of $1000 \mathrm{~m}$ was thrown respectively around the settlement areas in order to get the effect of the social impact depending on the population. The maps of the LCU belonging to the years 1987 and 2013 of the Alucra FPU of by the result of the analyses were derived and questioned numerically in the study. In general, the evaluation of the data obtained with the land inventory has been effective in determining the socio-economic factors. For this reason, social interaction in forested areas is directly influenced by the expansion of the settlements due to population.

Table 1. Land use class identification in Alucra FPU

\begin{tabular}{ll}
\hline Land use class & General Description \\
\hline $\mathrm{Cs}$ & Pinus sylvestris \\
$\mathrm{A}$ & Abies nordmanniana ssp. nordmanniana \\
$\mathrm{J}$ & Juniperus \\
$\mathrm{Q}$ & Quercus ssp. \\
$\mathrm{P}$ & Populus ssp. \\
$\mathrm{Cs}+\mathrm{P}$ & Pinus sylvestris + Abies nordmanniana ssp. nordmanniana, \\
$\mathrm{A}+\mathrm{Cs}$ & Abies nordmanniana ssp. nordmanniana + Pinus sylvestris \\
$\mathrm{A}+\mathrm{P}$ & Abies nordmanniana ssp. nordmanniana + Populus ssp. \\
$\mathrm{J}+\mathrm{P}$ & Juniperus + Populus ssp. \\
$\mathrm{P}+\mathrm{Cs}$ & Populous ssp. + Pinus sylvestris \\
$\mathrm{Q}+\mathrm{P}$ & Quercus ssp. + Populus ssp. \\
\hline
\end{tabular}


Table 1 (continued)

\begin{tabular}{ll} 
Table 1 (continued) & \\
\hline RegFor & Regenerated forest \\
DegFor & Degraded Forest \\
ForOp & Forest openings \\
Sandy & Sandy area \\
W & Water \\
Setl & Settlement \\
Agr & Agriculture land \\
\hline
\end{tabular}

\section{Results and Discussion}

The change of land use in time depends on the planning of future periods. In this study, the changes of land cover in Alucra FPU in the Forest Directorate of Giresun. It was also considered that the population showed what kind of change occurred in this area over time while the putting the time wise changes forth. It was also searched that what kind of social impact had on the forest's resources depending on the population.

When the 1985 to 2000 years population was migrated from Alucra to another area. The population had increased fast through the years 1980-1985 because people from the neighboring (Alucra, Çamoluk) was immigrated to Alucra. The population decreased gradually from the years 2000 to 2013 (Table 2). The population in the years 2013 and 1985 decreased nearly 50\% because there was migration from Alucra to the metropolitan cities of Turkey (Istanbul, Ankara, İzmir, Bursa, Antalya) (TUIK, 2013a).

Table 2. Demographic changes in Alucra

\begin{tabular}{cccc}
\hline Years & $\mathbf{1 9 8 0}$ & $\mathbf{1 9 8 5}$ & $\mathbf{2 0 1 3}$ \\
\hline Rural & 14855 & 22838 & 4594 \\
\hline Urban & 8823 & 10470 & 4130 \\
\hline Total & 23678 & 33308 & 9170 \\
\hline
\end{tabular}

\section{Evaluation of the Land Use Classes}

This study became the first in the scope of putting forth the time wise change of the land use classes. Table 3 was shown land usage changes in this study that was derived from data from 1987 to 2013. The general area of the Alucra FPU is 70811.3 ha as there is no change between 1987 and 2013. When looked at the change of the LUC generally, a great rate of increase such as $2.98 \%$ (increase
14038.3 ha) occurred in the productive forests in 2013.

One of the greatest reasons of this change is that the social impact decreases due to the immigration from Alucra. According to TUIK (2013b) demographic data, the total of the populations in centers and villages of Alucra became 9170 in the year 2013 while it was 33308 in the year 1985. Within the boundaries of Alucra FPU, there is a decrease of 5091.0 ha in degraded forest lands. The 1199.2 ha of degraded forest lands have occurred productive forest lands and there are no trees in 3870.2 ha of degraded forest lands. Settlement areas have diminished because of migration from villages.

There are successful reforestation activities (685.5 ha). Another great increase also occurred in the forest openings. The forest openings reached 19735.6 ha with an increase at rate of approximately $\% 14.57$ in the year 2013 while it was 41882.8 ha in the year 1987. With the accepted Pasture Law Numbered 4342 on 25 February 1998, pastures area class was changed into forest openings. It is essential to approve those areas in the commission together with their title land register considered by the forest and grassland commissions. It was another reason that the agricultural lands transformed to the forestlands in land cover map in 2013. That is why the population decreased in settlement area as most of the agricultural and grassland lands used by people in 1987 were recorded as the pasture area in the plan. Kılıçkaya Dam, used for watering and generating energy, started in 1987 and finished in 1994. As another important change in the agricultural lands; it was 52150.3 ha in 1987, then it decreased $20.95 \%$ in 2013, 23770.8 ha. All values of land usage change have been shown in Figure 2, Figure 3, Table 3 and Table 4. 
Table 3. Land usage changes between 1987 and 2013

\begin{tabular}{lrrr}
\hline Land use & $\mathbf{1 9 8 7}$ & $\mathbf{2 0 1 3}$ & $\begin{array}{c}\text { Transition } \\
\mathbf{2 0 1 3}-1987\end{array}$ \\
\hline $\begin{array}{l}\text { Productive } \\
\text { Forest }\end{array}$ & 11465.4 & 25503.6 & 14038.3 \\
\hline $\begin{array}{l}\text { Degraded } \\
\text { Forest }\end{array}$ & 28094.6 & 23003.6 & -5091.0 \\
\hline $\begin{array}{l}\text { Forest } \\
\text { Openings }\end{array}$ & 41882.8 & 61618.4 & 19735.6 \\
\hline Agriculture & 52150.3 & 23770.8 & -28379.5 \\
\hline Settlement & 1282.2 & 1190.9 & -91.3 \\
\hline Water & 182.8 & 133.6 & -49.2 \\
\hline Sandy & 383.0 & 220.1 & -162.9 \\
\hline Total & 135441.0 & 135441.0 & \\
\hline
\end{tabular}

Table 4. The changes of LULC in Alucra FPU from 1987 to 2013

\begin{tabular}{|c|c|c|c|c|c|c|c|c|c|c|c|c|c|}
\hline \multirow{2}{*}{\multicolumn{2}{|c|}{$\begin{array}{c}\text { Land use } \\
\text { class }\end{array}$}} & \multicolumn{12}{|c|}{1987 land use class } \\
\hline & & Cs & $\mathbf{A}$ & $\mathbf{Q}$ & $\mathbf{C s}+\mathbf{P}$ & $\mathrm{A}+\mathrm{Cs}$ & DegFor & ForOp & Sandy & $\mathbf{W}$ & Setl & Agr & Total \\
\hline \multirow{19}{*}{ 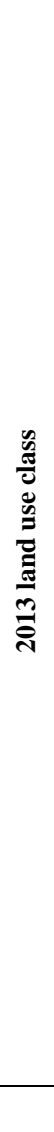 } & Cs & 5016.5 & 8.2 & 7.1 & 354.3 & 73.4 & 3358.7 & 1080.7 & & & 2.4 & 730.3 & 10631.5 \\
\hline & A & 6.6 & 110.7 & & & 63.9 & 77.3 & 97.1 & & & & 5.0 & 360.6 \\
\hline & $\mathrm{J}$ & & & & & & 14.3 & 0.8 & & & & 1.8 & 16.9 \\
\hline & Q & 49.0 & & 114.7 & 5.9 & 2.9 & 1825.4 & 211.1 & 3.7 & & 2.2 & 228.8 & 2443.8 \\
\hline & $\mathrm{P}$ & 23.0 & 3.6 & & 2.1 & & 200.5 & 175.5 & & & 0.7 & 121.8 & 527.3 \\
\hline & $\mathrm{Cs}+\mathrm{P}$ & 1729.6 & 56.7 & 28.6 & 490.7 & 246.2 & 3950.0 & 840.9 & & & 3.5 & 795.7 & 8142.1 \\
\hline & $\mathrm{A}+\mathrm{Cs}$ & 321.4 & 145.4 & & & 816.9 & 467.7 & 223.1 & & & 0.1 & 38.2 & 2012.9 \\
\hline & $\mathrm{A}+\mathrm{P}$ & & 5.1 & & & 2.6 & 12.2 & 7.0 & & & & 0.5 & 27.3 \\
\hline & $\mathrm{J}+\mathrm{Q}$ & 2.4 & & & & 1.8 & 139.8 & 14.5 & & & & 3.8 & 162.3 \\
\hline & $Q+P$ & 4.6 & 0.5 & & 5.3 & & 144.9 & 14.2 & & & & 22.5 & 191.9 \\
\hline & $\mathrm{P}+\mathrm{Cs}$ & 12.6 & & & 2.5 & 3.3 & 163.7 & 45.4 & & & 0.2 & 73.7 & 301.4 \\
\hline & RegFor & 1.7 & 1.1 & & & 0.1 & 20.7 & 340.5 & & & & 321.5 & 685.5 \\
\hline & DegFor & 674.5 & 38.4 & 302.2 & 71.4 & 112.7 & 11644.9 & 3870.2 & 41.6 & 7.2 & 30.7 & 6209.7 & 23003.6 \\
\hline & ForOp & 282.2 & 27.8 & 49.7 & 27.1 & 42.9 & 4318.9 & 32752.5 & 22.3 & 21.0 & 112.0 & 23962.1 & 61618.4 \\
\hline & Sandy & & & 3.6 & & & 3.5 & & 111.2 & 39.4 & 0.1 & 62.4 & 220.1 \\
\hline & W & 0.1 & & & & & 3.1 & 7.0 & 32.8 & 44.6 & 0.5 & 45.5 & 133.6 \\
\hline & Setl & 0.3 & & 0.3 & & & 44.7 & 73.5 & 1.9 & 0.5 & 625.7 & 443.9 & 1190.9 \\
\hline & Agr & 33.6 & 11.1 & 44.4 & 20.8 & 1.2 & 1704.3 & 2128.9 & 169.5 & 70.0 & 504.0 & 19082.9 & 23770.8 \\
\hline & Total & 8158.1 & 408.6 & 550.6 & 980.0 & 1368.0 & 28094.6 & 41882.8 & 383.0 & 182.8 & 1282.2 & 52150.3 & 135441.0 \\
\hline
\end{tabular}




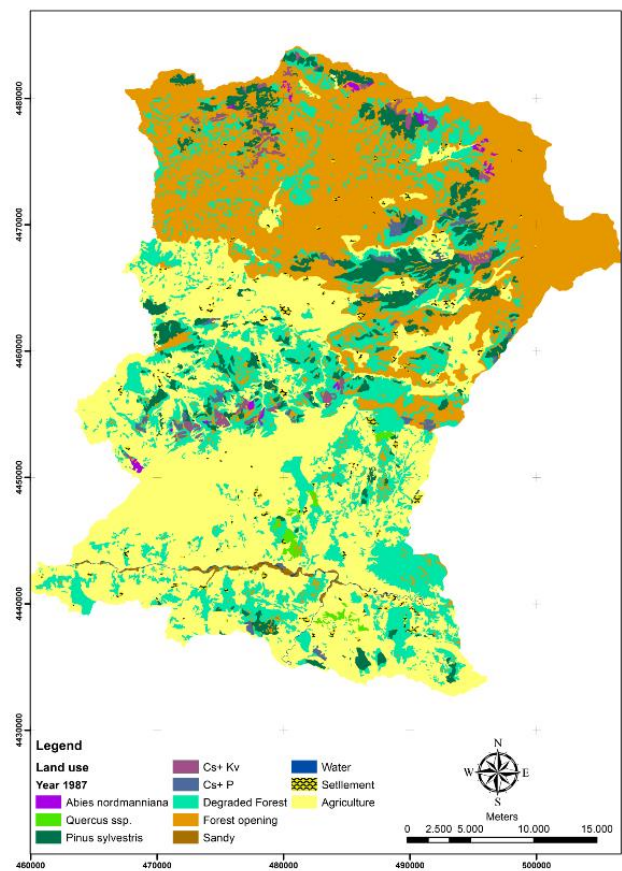

Figure 2. Land use 1987 in Alucra FPU

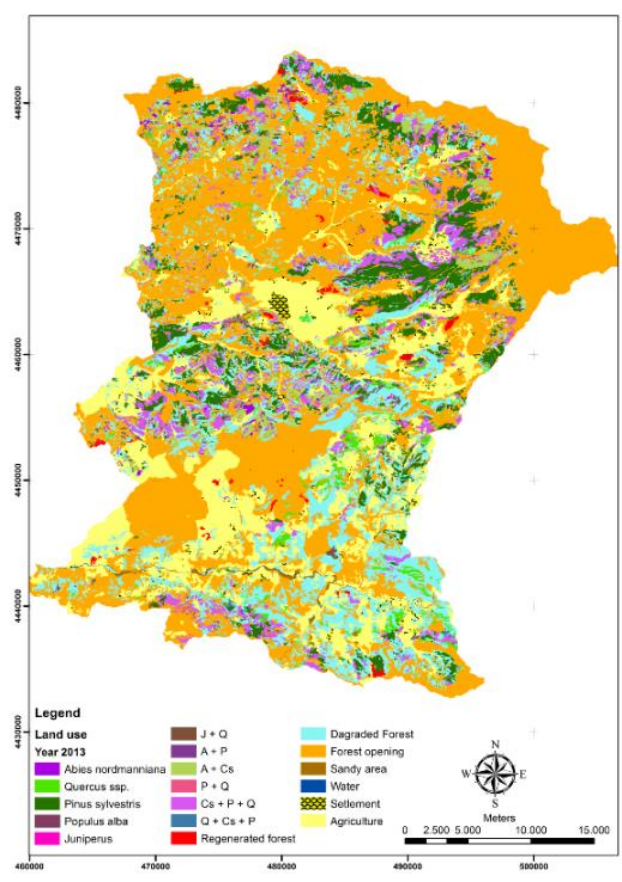

Figure 3. Land use 2013 in Alucra FPU
Evaluation of the Zones Thrown into the

Settlement Places Thorough Forests

The study is to show the effect of the change in the settlement areas on forests. In other words, it is to introduce the effect of social impact on forests depending on population. For this purpose, the buffers were thrown around the settling areas at specific intervals. These intervals are in the shape of squares with radiuses of $1000 \mathrm{~m}$ (Table 5). Then, it was revealed what kind of a change in the areas within this settlement zone.

Table 5 illustrates population changes in the village and town centers, and land use changes. The names of villages and towns in these population changes are kept the same in the records. The village population in rural areas generally decreases while increasing in county and towns. As considered land changes in the village centers, poplar and pine tree species cover emptied areas. It is found that the forest lands used as illegal during the past 28 years are taken into forest regime through the updated cadaster case. Other scattered settlement areas are not considered. Accordingly, areas of 1546.6 ha in the total of 64 settlement areas are converted into productive forest lands. Areas of 1154.7 ha go out of the forest. The forest lands have also increased with reforestation activities. In the study area, a water surface of 21.1 ha including water ponds and dams is formed. General changes are also presented in Table 5.

The number of patches increases according to the evaluations of FRAGSTAT results realized in the field. The increase of patch amount in forest land has showed that there are more interventions to forest lands. Mean patch size decreased from 60.95 to 14.70 . The other change values are given in Table 6. 
Table $5.1000 \mathrm{~m}$ zone settlement areas and land use change values

\begin{tabular}{|c|c|c|c|c|c|c|c|c|c|c|c|c|c|}
\hline & Popul & tion & & & & ANSFO & RM TO I & AND USE & CATE & GORY & & & $\stackrel{\mathscr{J}}{\leftrightarrows}$ \\
\hline 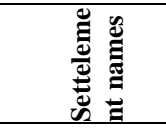 & $\ddot{\circ}$ & $\stackrel{m}{\vec{乛}}$ & 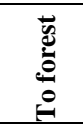 & 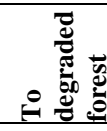 & oิ & 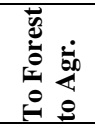 & 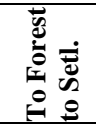 & 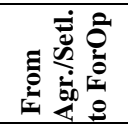 & 总 $\stackrel{9}{\dot{4}}$ & 量焉 & $\Leftrightarrow \frac{\grave{\Xi}}{\tilde{\sigma}}$ & Z & 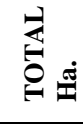 \\
\hline Akçiçek & 175 & 55 & 24.2 & 9.9 & 2.5 & 3.6 & 0.8 & 76.8 & 4.2 & 1.0 & & 191.3 & 314.2 \\
\hline Aktepe & 862 & 347 & 11.0 & 5.1 & 5.3 & 2.7 & & 44.6 & 4.2 & 8.7 & & 232.4 & 314.2 \\
\hline Akyap1 & 306 & 148 & & 2.0 & 0.1 & 15.7 & 0.4 & 7.6 & 10.4 & 0.6 & & 277.4 & 314.2 \\
\hline Altınova & 685 & 266 & 1.9 & 3.7 & 2.1 & & & 30.5 & & & & 20.1 & 58.3 \\
\hline Alucra & $\begin{array}{r}1047 \\
0 \\
\end{array}$ & 4130 & 40.3 & 5.9 & 12.5 & 0.9 & & 17.6 & 120.7 & & 0.6 & 115.7 & 314.2 \\
\hline Arda & 439 & 96 & 14.7 & 18.4 & 9.5 & 70.1 & 1.6 & 30.2 & 1.9 & 37.8 & & 129.9 & 314.2 \\
\hline Ardıç & 76 & 39 & 30.7 & 29.3 & 4.7 & 16.3 & 1.1 & 1.3 & & 0.4 & & 230.3 & 314.2 \\
\hline Armutlu & 216 & 69 & 3.2 & 0.9 & 0.1 & 33.0 & 0.8 & 0.1 & & 2.6 & & 273.4 & 314.2 \\
\hline Aydınyayla & 114 & 27 & 44.5 & 35.7 & 21.9 & 67.2 & 1.4 & 8.1 & & 1.5 & & 133.9 & 314.2 \\
\hline Bayırköy & 217 & 184 & & 6.7 & 10.3 & 3.6 & & 114.7 & & & 4,8 & 39.0 & 179.1 \\
\hline Bereketli & 91 & 52 & 53.6 & 41.4 & 7.0 & 39.3 & 3.8 & & & & & 169.1 & 314.2 \\
\hline Beylerce & 75 & 25 & 20.3 & 46.4 & 16.1 & 20.5 & 0.4 & 0.4 & & 0.3 & & 209.8 & 314.2 \\
\hline Boyluca & 739 & 230 & 47.0 & 4.9 & 0.1 & 15.5 & 0.8 & 13.3 & 11.8 & 5.0 & & 215.8 & 314.2 \\
\hline Çakılkaya & 477 & 115 & 36.8 & 26.1 & 7.3 & 6.4 & 0.1 & 70.4 & 3.5 & 11.2 & & 152.2 & 314.2 \\
\hline Çalgan & 567 & 258 & 32.7 & 7.2 & 4.1 & 0.6 & & 50.2 & 5.0 & 1.8 & & 212.6 & 314.2 \\
\hline Çamliyayla & 342 & 188 & 56.4 & 36.9 & 15.5 & 0.2 & 0.3 & 97.9 & 3.3 & 7.0 & & 96.6 & 314.2 \\
\hline Çamoluk & 1335 & 3137 & 3.8 & 11.3 & 4.8 & 1.3 & 0.4 & 97.0 & 13.3 & 17.7 & 3,9 & 160.5 & 314.2 \\
\hline Daldibi & 52 & 23 & 2.8 & 74.7 & 3.9 & 6.4 & 0.5 & 44.7 & 0.4 & 4.1 & & 176.6 & 314.2 \\
\hline Demirözü & 755 & 258 & 17.3 & 6.7 & 10.5 & 10.5 & 0.3 & 72.0 & 2.4 & 3.7 & & 190.7 & 314.2 \\
\hline Dereçiftlik & 98 & 122 & 24.8 & 19.5 & & 42.6 & 1.0 & & 0.4 & 9.9 & & 215.9 & 314.2 \\
\hline Doludere & 397 & 138 & 22.1 & 8.9 & 4.4 & 2.3 & & 86.6 & & 25.1 & & 164.7 & 314.2 \\
\hline Dönençay & 83 & 46 & 1.5 & 7.0 & 1.2 & 0.1 & & 142.5 & & & & 121.8 & 274.0 \\
\hline Eğnir & 197 & 138 & & 48.5 & 4.0 & 31.2 & 4.2 & 34.7 & 2.0 & 1.2 & 2.8 & 185.5 & 314.2 \\
\hline Elmacık & 155 & 125 & 85.6 & 9.0 & 1,7 & 3.1 & & 14.2 & 2.8 & 0.4 & & 197.3 & 314.2 \\
\hline Fevziçakmak & 611 & 201 & 19.7 & 12.2 & 6,9 & 4.4 & 1.5 & 20.3 & 3.4 & 5.9 & & 239.9 & 314.2 \\
\hline Findıklı & 145 & 50 & 5.6 & 40.5 & 11.9 & 16.0 & 0.9 & 92.1 & 9.3 & 2.3 & 3.9 & 131.7 & 314.2 \\
\hline Gökçebel & 229 & 34 & 104.3 & 8.9 & 5.3 & 13.8 & 0.7 & 16.4 & 2.3 & 1.0 & & 161.5 & 314.2 \\
\hline Gücer & 550 & 112 & 17.0 & 131.6 & 0.1 & 1.5 & & 27.1 & & 4.4 & & 132.6 & 314.2 \\
\hline Günügüzel & 255 & 91 & 26.9 & 6.2 & 4.5 & 5.0 & & 38.2 & 5.0 & 3.5 & & 224.8 & 314.2 \\
\hline Gürçalı & 262 & 197 & & & & & & & & & & 32.1 & 32.1 \\
\hline Haciahmet & 494 & 160 & & 14.8 & 0.3 & 16.4 & 4.6 & 96.6 & 9.6 & 1.6 & & 170.1 & 314.2 \\
\hline Hacihasan & 247 & 167 & 11.2 & 11.9 & 2.5 & 71.0 & 1.6 & 49.0 & 5.2 & 8.9 & & 153.0 & 314.2 \\
\hline Hacilı & 125 & 62 & & 2.0 & 0.3 & 1.3 & & 27.7 & 5.5 & 3.1 & & 274.2 & 314.2 \\
\hline Haciören & 93 & 87 & 24.0 & 75.5 & 21.7 & 6.8 & 0.4 & 51.8 & 1.4 & & & 132.5 & 314.2 \\
\hline İğdecik & 228 & 77 & 34.2 & & & 3.0 & & 9.4 & 2.6 & 4.3 & & 260.7 & 314.2 \\
\hline Kabaktepe & 68 & 34 & 48.9 & 37.1 & 0.6 & 5.7 & & 50.6 & 0.9 & 2.6 & & 167.8 & 314.2 \\
\hline
\end{tabular}




\section{Table 5 (continued)}

\begin{tabular}{|c|c|c|c|c|c|c|c|c|c|c|c|c|c|}
\hline Kaledere & 405 & 161 & 31.0 & 22.7 & 2.5 & 3.1 & 0.1 & 94.9 & 2.8 & 2.6 & & 154.5 & 314.2 \\
\hline Kaledibi & 186 & 72 & 11.6 & 15.8 & 0.8 & 75.1 & & 6.4 & & 5.1 & & 199.4 & 314.2 \\
\hline Kamışlı & 231 & 115 & 57.9 & 13.6 & 20.5 & 11.3 & & 27.9 & 9.6 & 1.9 & 2.9 & 168.6 & 314.2 \\
\hline Karabörk & 901 & 439 & 69.2 & 26.7 & 3.2 & 43.3 & 4.2 & 1.1 & 3.6 & 2.2 & & 160.7 & 314.2 \\
\hline Karadikmen & 1009 & 286 & 13.0 & 44.4 & 17.3 & 4.4 & & 100.4 & 1.0 & 3.8 & & 129.9 & 314.2 \\
\hline Kayacık & 13 & 30 & 50.2 & 26.8 & 13.1 & 10.6 & & 1.4 & 0.6 & 1.8 & & 209.7 & 314.2 \\
\hline Kaynar & 336 & 129 & 17.7 & 52.1 & 16.7 & 21.7 & & 51.6 & 0.7 & 6.3 & 0.7 & 146.6 & 314.2 \\
\hline Kilıçtutan & 257 & 173 & 34.9 & 73.3 & 18.2 & 22.9 & 0.1 & 19.3 & 0.4 & 0.4 & & 144.6 & 314.2 \\
\hline Koçak & 125 & 103 & & 25.5 & 19.3 & 0.2 & & 176.6 & & 1.4 & & 65.7 & 288.7 \\
\hline Köklüce & 680 & 151 & 48.3 & 36.3 & 13.8 & 5.3 & 2.4 & 60.6 & 1.3 & 6.4 & & 139.7 & 314.1 \\
\hline Koman & 234 & 111 & 7.3 & 8.0 & 1.6 & 12.9 & & 12.2 & 3.1 & 3.3 & & 265.8 & 314.2 \\
\hline Konaklı & 69 & 29 & 3.4 & 1.1 & 0.5 & 9.4 & & 62.0 & 0.1 & & & 237.7 & 314.2 \\
\hline Kutluca & 548 & 232 & 3.0 & 13.3 & 84.7 & 10.5 & 3.1 & 72.9 & 3.8 & 7.7 & & 115.2 & 314.2 \\
\hline Örencik & 218 & 126 & 75.8 & 11.1 & 18.5 & 1.4 & & 104.7 & 0.6 & 3.1 & & 98.9 & 314.2 \\
\hline Ozanköy & 82 & 55 & 9.1 & 36.1 & 12.8 & 4.8 & 1.1 & 139.8 & 1.1 & 3.4 & & 106.1 & 314.2 \\
\hline Pirili & 82 & 44 & 35.6 & 6.4 & 0.3 & 1.5 & 0.1 & & 2.4 & 3.4 & & 264.5 & 314.2 \\
\hline Sarpkaya & 359 & 172 & & 25.3 & 14.9 & 1.8 & & 110.1 & & 5.1 & & 107.4 & 264.6 \\
\hline Subaşı & 139 & 44 & 2.6 & & & 73.5 & 2.8 & 0.4 & & 0.1 & & 234.8 & 314.2 \\
\hline Suyurdu & 149 & 77 & 5.4 & 14.0 & 7.6 & 24.6 & 3.8 & 38.9 & 0.1 & 2.0 & & 217.7 & 314.2 \\
\hline Taşcılar & 156 & 85 & 35.5 & 47.8 & 69.8 & 4.5 & 0.1 & 53.2 & 5.4 & & & 97.9 & 314.2 \\
\hline Taşdemir & 476 & 170 & 8.4 & 4.2 & 0.2 & 17.0 & & 6.4 & & 0.3 & & 277.8 & 314.2 \\
\hline Tepeköy & 301 & 163 & 5.6 & 8.6 & 9.0 & 35.0 & & & & & & 256.0 & 314.2 \\
\hline Usluca & 774 & 329 & 8.4 & 56.1 & 5.3 & 14.3 & 3.8 & 19.2 & 2.8 & 8.8 & 0.5 & 195.0 & 314.2 \\
\hline Yenice & 1503 & 819 & 14.9 & 34.8 & 9.5 & 40.6 & 3.6 & 2.7 & 5.5 & 10.3 & 1.0 & 191.3 & 314.2 \\
\hline Yeniköy & 399 & 122 & & 13.1 & 5.6 & 8.0 & & 90.5 & 4.8 & 10.9 & & 181.4 & 314.2 \\
\hline Yeşilyurt & 999 & 793 & 59.7 & 4.2 & 11.7 & 58.2 & 2.8 & 0.1 & 14.9 & 7.8 & & 154.8 & 314.2 \\
\hline Yükselen & 256 & 32 & 34.1 & 62.3 & 8.6 & 10.7 & & 72.0 & 0.5 & 7.4 & & 118.6 & 314.2 \\
\hline Yusufeli & 191 & 113 & 36.7 & 14.5 & 1.5 & 34.1 & 0.5 & 16.9 & 0.2 & 2.9 & & 207.0 & 314.2 \\
\hline TOTAL & 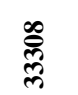 & $\begin{array}{l}\text { : } \\
\text { : }\end{array}$ & 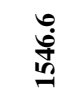 & $\begin{array}{l}n \\
\stackrel{n}{8} \\
\stackrel{8}{n}\end{array}$ & ڤิ) & $\begin{array}{l}\mathscr{n} \\
\stackrel{0}{\theta} \\
\hat{\theta}\end{array}$ & ชั่ & 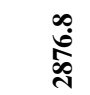 & बें & $\begin{array}{l}\text { के } \\
\text { के }\end{array}$ & $\overline{\dot{\Delta}}$ & $\begin{array}{l}\hat{\theta} \\
\hat{\theta}\end{array}$ & $\frac{\vec{\infty}}{\sigma}$ \\
\hline
\end{tabular}


Table 6. FRAGSTAT results in 1987 and 2013

\begin{tabular}{|c|c|c|c|c|c|c|c|c|c|c|c|}
\hline Year & CA & NP & MPS & MSI & MPFD & PSSD & $\begin{array}{l}\text { PERC } \\
\text { LAND }\end{array}$ & TA & LPI & PD & PSCV \\
\hline 1987 & 135441 & 2222 & 60.95 & 1.64 & 1.31 & 1186.06 & 100.0 & 135441.0 & 30.01 & 1.64 & 1945.80 \\
\hline 2013 & 135441 & 9212 & 14.70 & 1.98 & 1.37 & 356.76 & 100.0 & 135441.0 & 24.27 & 6.80 & 2426.51 \\
\hline Year & AWMSI & DLFD & AWMPFD & SHDI & SIDI & MSIDI & SHEI & SIEI & MSIEI & PR & PRD \\
\hline 1987 & 14.34 & 1.31 & 1.40 & 1,42 & 0.71 & 1.24 & 0.59 & 0.78 & 0.52 & 11.0 & 0.00812 \\
\hline 2013 & 12.17 & 1.37 & 1.41 & 1.63 & 0.72 & 1.28 & 0.56 & 0.77 & 0.44 & 18.0 & 0.01328 \\
\hline
\end{tabular}

\section{Conclusions}

It is found that the forestry area of the Alucra FPU increase recent years. The reasons for the increase of forest areas are the completed successful forestry activities and the decrease in social impact caused by migration from rural to the urban areas. In addition to the reforestation recent years may be given samples for the successful forestry activities.

Pasture commission works should be completed primarily with interdisciplinary approach. Actual land cover data such as grassland, settlement and agriculture should be processed simultaneously to forest management plan. With the multiple purpose of forest functions which is ecological and socio cultural functions should be applied beside the economical function in the forest management plans. The biodiversity data should be given numerically in order to perform particularly forest ecosystem management plans in the numeric environment.

The forest ecosystem has been changed over time by the result of the human interferences and the natural events. The spatial change in this forest structure varies depending on the human factor in the region, the intensity of natural phenomena and the prolificacy of the land (Ün, 2006). Changing of landform from human activities may be determined the spatial configuration of landscape structure. Landscape structure characterizes composition and configuration of the land cover classes (McGarigal and Marks, 1995).

However, the determination of the main factors affecting the change in land use in Turkey day by day more studies has been conducted. In order to manage the ecosystem and minimize negative environmental impacts, it is important how the structure of forest ecosystems is affected as well as spatial identification of the change in land use
(Barlow, Mestre, Gardner \& Peres, 2007; Lira, Tambosi, Ewers \& Metzger, 2012).

The remote sensing inventory was made to update the forest ecosystem data. This allows us to obtain accurate, fast and low cost data by using remote sensing (Musaoğlu, 1999). Thanks to the information technologies we use, we ensure the efficient use of information to guide the next planning. It is possible to use this process together with GIS and remote sensing from today's information technologies (Çakır, 2006).

As the grasslands of the area are insufficient for animals, the grassing is generally made in the plateaus in the forest lands. The animals such as mandate, horse, donkey and mule are not lot in the area, but the ranch of animals like sheep, goat, cattle and the poultry have been increasing.

The ownership of the forests in Turkey, $99 \%$ is in the hands of state-controlled giant and is also making forest management plans. Forestry studies in our country are carried out in accordance with large scale map construction regulations. Particularly the forest openings, agricultural, and settlement areas should be distinguished rather well in the forest management plans. Different land cover maps created for management could be used effectively. It is observed that the degraded forest areas are very much within the boundaries of the Alucra Forest Planning Unit. Rehabilitation activities in the degraded forest areas should be accelerated and the necessary labor force opportunities should be increased. Especially in the areas where afforestation works will be carried out, suitable tree species should be selected for the field.

The socio-economic conditions of the population need to be improved in order to eliminate the social effects on the forests and to prevent the decrease of the population in the villages. In addition, different livelihoods should be provided to livelihoods for the people in the region. It is necessary to improve 
socio-economic conditions of the people in order to eliminate their social impact on forests and to prevent the population decrease in the villages. In addition, the different living resources should be provided for the people in the region ensuring their livings with the livestock.

One of the pressure of forest lands in Alucra is the human impact. This impact has continued decreases depending on decline of demography recent years. In addition to eliminate to social pressure in the region should be informed in local people. They can be increased annual income which is included in the activities of collecting pine cones, dry trees and their branches. According to the participation principle, the wishes of the people should be also taken into consideration when the forest management plans are prepared.

\section{References}

Anonymous, (1987). Giresun Forest Regional Directorate, Alucra Forest Planning Unit, Forest Management Plan of Alucra Forest Planning Unit Between 1987 and 2006, Giresun (Press Turkish).

Anonymous, (2013). Giresun Forest Regional Directorate, Alucra Forest Planning Unit, Forest Management Plan of Alucra Forest Planning Unit Between 2013 and 2032, Giresun. (Press Turkish).

Barlow, J., Mestre, L.A.M., Gardner, T.A. \& Peres, C.A. (2007). The value of primary, secondary and plantation forests for Amazonian birds. Biological Conservation, 136(2), 212-231. https://doi.org/10.1016/j.biocon.2006.11.021.

Bayram, S. (2014). Alucra Orman İşletme Şefliğinin Sosyo-Ekonomik Koşullara Göre Zamansal Değişiminin Belirlenmesi, MSc Thesis, Gümüşhane Universitesi Fen Bilimleri Enstitüsü, Ormanclık ve Çevre Bilimleri Anabilim Dalı, 59p (Press Turkish).

Bhatta, B.R., Chalise, S.R., Myint, A.K. \& Sharma, P.N. (1999). Recent Concepts, Knowledge, Practices, and New Skills in Participatory Integrated Watershed Management: Trainers Resource Book. ICIMOD, PWMTA-FAO, and Department of Soil Conservation and Watershed Management, Nepal.

Çakır, G. (2006). Establishing Spatial Data Base for Forest Management Planning Using Remote Sensing and Geographic Information Systems, PhD Thesis, Karadeniz Technical University, Graduate School Natural and
Applied Science, Trabzon, 127p. (Press Turkish)

Çakır, G., Köse, S., Başkent, E.Z. (2010). Orman Amenajman Planlarında Yol, Dere Yatağı ve Enerji Nakil Hatlarının Poligon Olarak Gösterilmesi ve Oluşturduğu Sonuçlar, Kastamonu University Journal of Forestry Faculty. 10 (1): 12-19 (Press Turkish).

Çakır, G. (2012). Eski Tarihli Meşcere Haritası ve Yüksek Çözünürlüklü Uydu Görüntüsü Yardımıyla Taslak Meşcere Haritası Üretilmesi, Kastamonu University Journal of Forestry Faculty. 12 (2): 278-284 (Press Turkish)

De Fries, R.S. \& Belward, A.S. (2000). Global and Regional Land Cover characterization from data: An Introduction to the Special Issue, International Journal of Remote Sensing, 21(67), 1083-1092. https://doi.org/10.1080/01431160 0210083.

FAO, (1994). The State of Food and Agriculture. Food and Agriculture Organization of the United Nations [FAO]. FAO Agriculture Series, 27. Rome, Italy.

GDF, (2013). Performance of program of General Directorate of Forestry in 2013. Turkish General Directorate of Forestry. Ankara, 433p.

Giri, C.P. (2012). Remote Sensing of Land Use and Land Cover, Principles and Applications, Section I Overview Chapter I Brief overview of Remote Sensing Land Cover, Taylor and Francis Series in Remote Sensing Applications, Edited by Chandra P. Giri, 3-12.

Günlü, A. \& Başkent, E.Z. (2017). Relationships between Soil Moisture and RADARSAT derived Backscattering Coefficient Values: a case studies in Artvin-Merkez and Gümüşhane-Karanlıkdere Forest Planning Units, Kastamonu University Journal of Forestry Faculty. 17 (1), 36-44.

Hensen, M.C. \& De Fries, R.S. (2004). Detecting Long-term Global Forest Change Using Continuous Fields of tree-cover maps from 8$\mathrm{km}$ advanced very high resolution radiometer [AVHRR] data for the years 1982-99, Ecosystems, 7(7), 695-716. http://dx.doi.org/10.1007\%2Fs10021-0040243-3.

Huang, Q., Cai, Y. \& Peng, J. (2007). Modeling the spatial pattern of farmland using GIS and multiple logistic regression: A case study of Maotiao River Basin, Guizhou Province, China. Environmental Modeling and Assessment, 12, 55-61. DOI 10.1007/s10666006-9052-8.

Jin-feng, H., Guo-jie, C. \& Zhong, Y.A. (2005). A Study of the driving force model revealing changes in land utilization level based on $3 \mathrm{~S}$ 
Technologies. Wuhan University Journal of Natural Science. 10 (4), 791-795. Article ID: 1007-1202(2005)04-0791-05.

Kammerbauer, J. \& Ardon, C. (1999). Land use dynamics and landscape change pattern in a typical watershed in the hillside region of central Honduras. Agriculture, Ecosystems \& Environment, 75, 93-100. PII: S01678809(99)00071-7

Karanth, K.K., Curran, L.M. \& Reuning-Scherer, J.D. (2006). Village size and forest disturbance in Bhadra Wildlife Sanctuary, Western Ghats, India. Biological Conservation, 128, 147-157. doi:10.1016/j.biocon.2005.09.024

Kelarestaghi, A. \& Jeloudar, Z.J. (2011). Land use/cover change and driving force analyses in parts of Northern Iran using RS and GIS techniques. Arabian Journal of Geosciences, 4, 401-411. DOI:10.1007/s12517-009-0078-5

Laurance, W.F. \& Bierregaard, Jr. R.O. (1997). Tropical Forest Remnants: Ecology, Management, and Conservation of Fragmented Communities. The University of Chicago Press, Chicago.

Lira, P.K., Tambosi, L.R., Ewers, R.M. \& Metzger, J.P. (2012). Land-use and land-cover change in Atlantic Forest landscapes. Forest Ecology and Management, 278, 80-89.

http://dx.doi.org/10.1016/j.foreco. 2012.05.008.

McGarigal, K. \& Marks, B.J. (1995). Spatial pattern analysis program for quantifying landscape structure. U.S. Forest Service General Technical Report, USA.

Musaoğlu, N. (1999). Determination of Stands type and Growth Media Units in Forest Areas by Satellite Data obtained from Electro-Optic and Active Microwave Detectors. $\mathrm{PhD}$ Thesis, İstanbul Technical University, Graduate School of Natural and Applied Sciences. İstanbul.

Naiman, R.J., Bisson, P.A. \& Turner, M.G. (1997). Approaches to management at the watershed scale. In: Kohm, K.A., Franklin, J.F. [Eds.], Creating a Forestry for the 21st Century: The Science of Ecosystem Management. Island Press.

Sharma, P.N. \& Krosschell, C. (1996). An approach to farmer-led sustainable upland watershed management. In: Sharma, P.N. [Ed.], Recent Developments, Status and Gaps in Participatory Watershed Management Education and Training in Asia [PWMTA]. PWMTA and FARM Programs, Kathmandu, Nepal.

Şen, G., Güngör, E. \& Şevik, H. (2018). Defining the effects of urban expansion on land use/cover change: a case study in Kastamonu,
Turkey. Environmental Monitoring and Assessment. $\quad 190, \quad 454$. https://doi.org/10.1007/s10661-018-6831-z

Triantakonstantis, D.P., Kollias, V.J. \& Kalivas, D.P. (2006). Forest re-growth since 1945 in the Dadia forest nature reserve in northern Greece. New Forests, 32, 51-69. DOI 10.1007/s11056005-3626-1

TUIK, (2013a). Alucra demographic resource by Turkish Statistics Institute, http://www.tuik.gov.tr [accessed on July 12, 2013].

TUIK, (2013b). Genel nüfus sayımları 2013, https://biruni.tuik.gov.tr/nufusmenuapp/menu. zul [accessed on March 11, 2013

Tunay, M. \& Ateşoğlu, A. (2004). Determination of Non-Natural Changes in Bartin Environ Using Remote Sensing Technique and GIS. Fatih University, $3^{\text {rd }}$ GIS Days, İstanbul.

URL-1, (2015). General Information about Alucra. http:// http://sebinubyo.giresun.edu.tr. [accessed on February 1, 2015].

Ün, C. (2006). Determination of Temporal Variation in Istanbul Forested Areas by means of Remote Sensing and GIS. Master Thesis, Karadeniz Technical University, Graduate School of Natural and Applied Sciences. Trabzon, 104p.

Vitousek P.M., Aber J.D, Howarth, R.W., Likens, G.E., Matson, P.A., Schindler, D.W., Schlesinger, W.H. \& Tilman, D. (1997). Human Alteration of The Global Nitrogen Cycle: Sources And Consequences. Ecological Applications. 7(3), 737-750.

Yavuz, M., Sağlam, B., Küçük, Ö. \& Tüfekçioğlu, A. (2018). Assessing forest fire behavior simulation using FlamMap software and remote sensing techniques in Western Black Sea Region, Turkey, Kastamonu University Journal of Forestry Faculty. 18 (2), 171-188.

Zaimes G.N., Kayıaoglu, K. \& Kozanidis, A. (2017). Land-use/vegetation cover and soil erosion impacts on soil properties of hilly slopes in Drama Prefecture of Northern Greece, Kastamonu University Journal of Forestry Faculty. 17 (3), 427-433. 